\title{
Communications
}

\section{Thiobarbituric Acid Derivatives for Anti-HCV Agents Targeting NS5B RNA Polymerase ${ }^{\dagger}$}

\author{
Hyun-Joon Ha, ${ }^{\star}$ Sang-Mi Han, Seung Whan Ko, ${ }^{7}$ Kyung Eun Cha, Jong-Ho Lee, and Heejoon Myung ${ }^{\S}$ \\ Protein Research Center for Bio-Indistry and Department of Chemistry, Hankuk University of Foreign Studies, \\ Yongin 449-791, Korea. "E-mail: hiha@hufs.ac.kr \\ Imagene Co. Ltd., Biotechnology Incubating Center, Seoul National University, Seoul 151-742, Korea

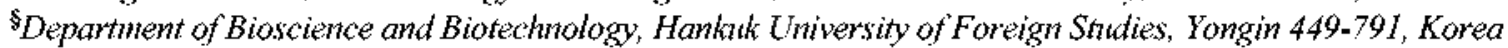 \\ Received Jily 3, 2007
}

Key Words : Thiobarbituric acid, IICV, NS5B RN $\Lambda$ polymerase, Inhibition

Hepatitis C virus (HCV) is an etiologic agent responsible for chronic liver disease including fibrosis, cinhosis and hepatocellular carcinoma. ${ }^{1}$ It is estimated that more than 170 million people, or $3 \%$ of entire world population, are infected with HCV. Although extensive research has been carried out, no vaccine is available with three to four million new infections every year. ${ }^{2} \mathrm{Up}$ to now the only available standard therapy to treat HCV is a combination of interferon- $\alpha$ and ribavirin. ${ }^{3}$ However, this therapy has many side effects and works for HCV genotype 1 only. Thereby more potent and broader medicines are urgently needed. Among the possible drug targets is the RNA polymerase of nonstructural protein $5 \mathrm{~B}$ (NS5B), which is essential for viral replication. ${ }^{4} \mathrm{~A}$ few compounds are under development for anti-HCV targeting NS5B RNA polymerase, which are classified into three different structural bases as nucleoside analogs, non- nucleoside analogs and pyrophosphate mimcs. ${ }^{3}$

The cell based assay method was established in our laboratory on the basis of the partial reconstitution of hepatitis $\mathrm{C}$ virus RNA polymerization by heterologous expression of NS5B polymerase and template RNA in bacterial cell. ${ }^{6}$ Each chemical was added to a culture of bacterial cell harboring the NS5B expressing plasmid and the reporter plasmid at the concentrations of 10,20 , and 40 $\mu \mathrm{M}$. Luciferase activity was measured in a luminometer. This allowed screening compound libraries to find out the lead molecule with unique heterocyclic structure of thiobarbituric acid. Thereby we decided to prepare many thiobarbituric acid derivatives (1) with diverse substituents denoted as $R^{1}, R^{2}$ and $R^{3}$ starting from thioisocyanate with amine to make thiouea (2) followed by cyclization with malonic acid in the presence of acetylchloride in more than $70 \%$ yield at most cases. ${ }^{7}$ Once we obtained thiobarbituric acid ring (3) various aldehydes were coupled to afford multisubstituted thiobarbituric acid derivatives (1) (Scheme 1).

In this manner fifty two different compounds were

${ }^{7}$ This paper is dedicated to Professor Sang Chul Shim on the occasion of his honorable retirement.

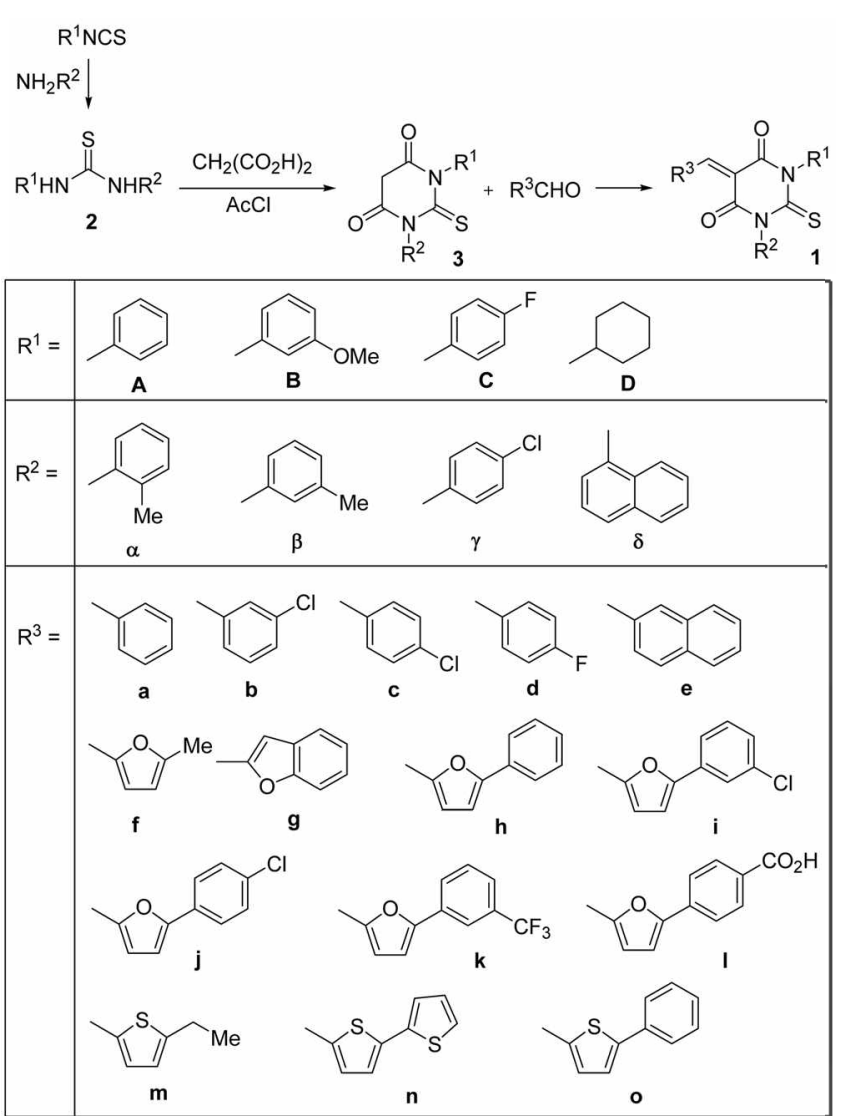

Scheme 1. Preparation of thiobarbituric acid derivatives (1) tested for anti-HCV agents targeting NS5B RNA polymerase.

elaborated and tested as an inhibitor of NS5B RNA polymerase, some of which shows comparably high activity as shown in Figure 1. The activity is not quite sensitive to the substituents of $\mathrm{R}^{1}$ and $\mathrm{R}^{2}$ while compounds with 2arylfuran or 2-arylthiofuran as $\mathrm{R}^{3}$ are more active. Most compounds with 2-thiofuaran showed cytotoxicity at more than $20 \mu \mathrm{M}$. All compounds consisted with smaller rings 


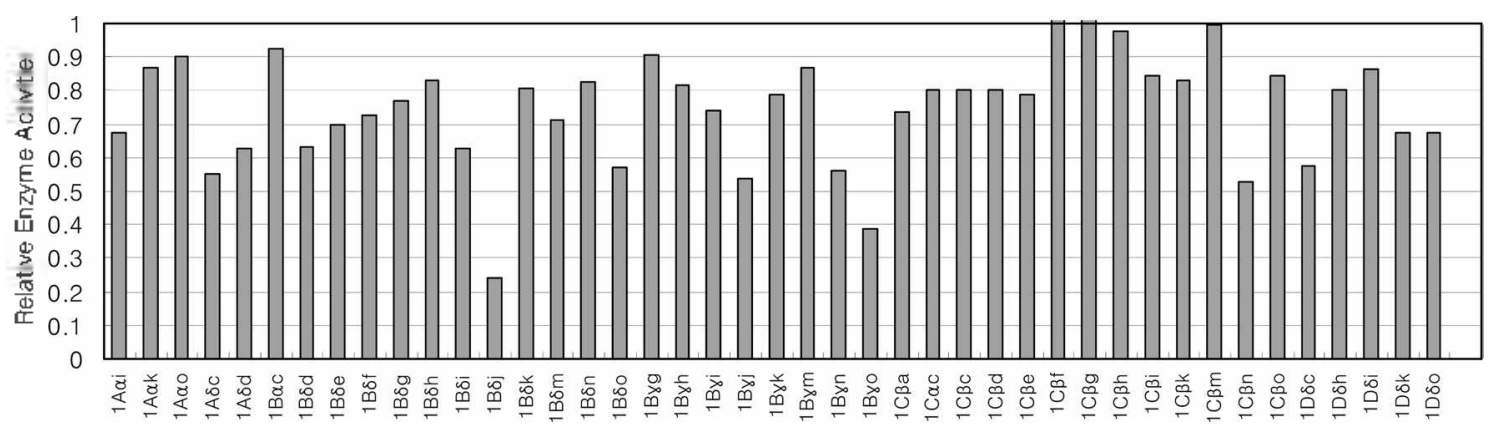

Figure 1. Relative NS5B RNA polymerase activity.

than thiobarbituric acid such as 2-thioxo-oxazolidin-4-one or 2-thioxo-thiazolidin-4-one were not active against the tested enzyme. For the further evaluation of the compounds the $\mathrm{IC}_{50}$ values $^{9}$ of the active compounds, $1 \mathbf{A} \alpha \mathbf{i}, 1 \mathbf{A} \delta \mathbf{c}, 1 \mathbf{B} \delta \mathbf{j}$, 1B $\gamma_{0}$ and $1 C \rho \mathrm{t}$ were measured to be $0.6,0.5,0.5,0.9$, and $1.0 \mu \mathrm{M}$ with reference of developing candidate GSK benzo1,2,4-thiadiazine analog ${ }^{10}$ number 1 as $0.6 \mu \mathrm{M}$ under the same assay condition.

One of the compounds $1 \mathrm{C} \beta \mathrm{n}$ found at early stage of this study has been validated with the isolated NS5B RNA polymerase. This compound is a non-competitive inhibitor to the enzyme with $\mathrm{K}_{\mathrm{i}}$ value $2.2 \mu \mathrm{M}$ to imply that the compound binds to the NS5B polymerase away form the active site which is located deep inside of enzyme. Based on the early discovery of the crystalline structure of enzyme ${ }^{\prime \prime}$ and inhibitor complex, our thiobarbituric acid derivative may bind the thumb side of enzyme. ${ }^{12}$ Further development and the more detailed biological evaluation will be reported in due course.

Acknowledgement. This work was supported by the Korea Research Foundation Grant funded by the Korean Government (MOEHRD, Basic Research Promotion Fund KRF-2006-312-C00582).

\section{References and Notes}

1. World Health Organization Wkly: Epidemiol. Rec. 1996, 7l, 346. 2. Wasley, A.; Alter, M. J. Semin. Liver Dis. 2000, 20 , I.

3. Manns, M. P.; McHutchison, J. G.; Gordon, S. C.; Rustoi, V. K.; Shiffinan. M. Lancet 2001. 358, 958.

4. (a) Tan, S. L.; Pause, A.; Shi, Y.; Sonenberg, N. Nat, Rev, Dntg Discov. 2002, 1, 867. (b) Walker, M. P.; Hong, Z. Curr. Opin. Pharmacol. 2002, 2, 534. (c) De Francesco, R.; Tomei, L.; Altamura, S.; Summa, V.; Migliaccio, G. Antiviral Res. 2003, 58,
1. (d) Lee, J.-H.; Nam, I. Y.; Myung, H. Mol. Cells 2006, 21, 330. 5. (a) Wu, J. Z,; Hong, Z. Curr. Drug Targets; Infectious Disorders 2003, 3, 207. (b) Kim, J.; Lee, M.; Kim, Y.-Z. Bull. Kor, Chem. Soc, 2005, 26, 285. (c) Kim, J.; Chong, Y. Bull. Kor: Chem. Soc. 2006, 27, 59 .

6. Lee, S.; Lee, J.-H.; Kee, Y.; Park, M.; Myung. H. Virts Res. 2005 , 114, 158.

7. Mackee, T. D.; Sulo, R. K.; Tibbius, T.; Sowadski, J. W003074497 (Priority US20020361246P).

8. Each every chemical was added to a culture of bacterial cell harboring the NS5B expressing plasmid and the reporter plasmid at the concentrations of 10.20 , and $40 \mu \mathrm{M}$. Luciferase activity was measured in a luminometer. The data shows the activity of only for the concentration $20 / \mathrm{M}$ in Figure 1 .

9. The incorporation of [ $\left.\alpha-{ }^{2} \mathrm{P}\right]$ UTP was measured as described previously. ${ }^{13 / 4}$ Reactions were carried out in a mixture $(50 \mu \mathrm{L})$ containing $20 \mathrm{mM}$ Tris- $\mathrm{HCl}$ (pH 7.5), $5 \mathrm{mM} \mathrm{MgCl}$. I mM DTT, $1 \mathrm{mM}$ EDTA, $10 / 1 \mathrm{Ci}\left[\alpha-{ }^{32} \mathrm{P}\right] \mathrm{TTP}$ (3000 Ci/mmol, Amersham Biosciences), $10 \mu \mathrm{M}$ UTP, $0.2 \mu \mathrm{g}$ poly(A)/ $/ \mathrm{g}$ o $(\mathrm{U}) 12$ (Amersham Biosciences), $1 \mu$ g purified NS5B. After a 90 min incubation at 30 ${ }^{\circ} \mathrm{C}$, the reactions were stopped by the addition of $10 \mu \mathrm{L}$ of $0.5 \mathrm{mM}$ EDTA. Following $\left[\alpha-{ }^{32}\right.$ P]UTP incorporation reaction, unincorporated nucleotides were removed using the QIA quick Nucleotide Removal kit (Qiagen). The incorporated radioactivity was quantified by a liquid scintillation counter.

10. Dhanak, D.; Dufly, K. J.; Johnston, V. K.; Lin-Goerke, J.; Darcy, M.; Shaw, A. N.; Gu, B.; Silverman, C.; Gates, A. T.; Nonnemacher, M. R.; Earnshaw, D. L.; Casper, D. J.; Kaura, A.; Baker, A.; Greenwood, C.; Gutshall, L. L.; Maley, D.; DelVecchio, A.; Macamon, R.; Hofmann, G A.; Alnoah, Z.; Cheng. H. Y.; Chan, G; Khandekar, S.; Keenan, R. M.; Sarisky, R. T. J. Biol. Chem, 2002, 277, 38322 .

11. Lesburg, C. A.; Cable, M. B.; Ferrari, E.; Hong, Z.; Mannarino, A. F.; Weber, P. C. Not. Snztct. Biol, 1999, 6,937.

12. Wang, M.; Ng. K. K.; Chemey, M. M.; Chan, L.; Yannopoulos, C. G; Bedard, J.; Morin, N.; Nguyen-Ba, N.; Alaoui-Ismaili, M. H.; Bethell, R. C.; James, M. N. J. Biol. Chem. 2003, 278, 9489.

13. Yamashita, T.; Kaneko, S.; Shirota, Y.; Qin, W.; Nomura, T.; Kobayashi, K.; Murakami, S. J. Biol. Chem. 1998, 273, 15479.

14. Behrens, S. E.; Tomei, L.; De Francesco, R. EMBO J. 1996, 15, 12. 